\title{
Fluorescent bioassays for toxic metals in milk and yoghurt
}

\author{
Mohammad Shohel Rana Siddiki ${ }^{1}$, Shunsaku Ueda ${ }^{1,2}$ and Isamu Maeda ${ }^{1,2^{*}}$
}

\begin{abstract}
Background: From a human health viewpoint, contaminated milk and its products could be a source of long-term exposure to toxic metals. Simple, inexpensive, and on-site assays would enable constant monitoring of their contents. Bioassays that can measure toxic metals in milk or yoghurt might reduce the risk. For this purpose, the green fluorescent protein (GFP)-tagged trans factors, ArsR-GFP and CadC-GFP, together with their cis elements were used to develop such bioassays.

Results: ArsR-GFP or CadC-GFP, which binds either toxic metal or DNA fragment including cis element, was directly mixed with cow's milk or yoghurt within a neutral pH range. The fluorescence of GFP, which is reflected by the association/dissociation ratio between cis element and trans factor, significantly changed with increasing externally added As (III) or Cd (II) whereas smaller responses to externally added Pb (II) and Zn (II) were found. Preparation and dilution of whey fraction at low pH were essential to intrinsic zinc quantification using CadC-GFP. Using the extraction procedure and bioassay, intrinsic Zn (II) concentrations ranging from 1.4 to $4.8 \mathrm{mg} / \mathrm{l}$ for milk brands and from 1.2 to $2.9 \mathrm{mg} / \mathrm{kg}$ for yoghurt brands were determined, which correlated to those determined using inductively coupled plasma atomic emission spectroscopy.

Conclusions: GFP-tagged bacterial trans factors and cis elements can work in the neutralized whole composition and diluted whey fraction of milk and yoghurt. The feature of regulatory elements is advantageous for establishment of simple and rapid assays of toxic metals in dairy products.
\end{abstract}

\section{Background}

Toxic metal contamination to foods causes major global health problems. Humans are exposed to toxic metals primarily from air, water, and food [1]. Pollution of foods with environmental toxic metals even in trace quantities has attracted considerable attention in the global era with rapid transportation. The simple and inexpensive monitoring of food pollution needs to be developed for reducing or eliminating the amounts of toxic elements into the environment. Milk and milk products provide good quality nutrients necessary for a strong healthy body and mind, and act as a primary source of nutrients in diets all around the world [2]. However, the presence of toxic elements in milk and milk products may create health problems especially for infants, school age children, and old people who consume large quantity of those products.

\footnotetext{
*Correspondence: i-maeda@cc.utsunomiya-u.ac.jp

'United Graduate School of Agricultural Science, Tokyo University of Agriculture and Technology, 3-5-8 Saiwaicho, Fuchu 183-8509, Japan

${ }^{2}$ Faculty of Agriculture, Utsunomiya University, 350 Minemachi, Utsunomiya 321-8505, Japan
}

\section{Biomed Central}

(c) 2012 Siddiki et al.; licensee BioMed Central Ltd. This is an Open Access article distributed under the terms of the Creative Commons Attribution License (http://creativecommons.org/licenses/by/2.0), which permits unrestricted use, distribution, and reproduction in any medium, provided the original work is properly cited.

Their presence in milk and its products is caused by different agricultural activities. Irrigation with toxic metalcontaminated water and use of pesticides, parasiticides, drugs, and environmental disinfectants to cows may result in toxic metal contamination in feeds [3], meat, and milk [4-6]. As the mammary glands are the most physiologically sensitive part of dairy cows, the input and output of toxic metals in these organisms are clearly reflected in the milk [7]. Heavy metals, specially cadmium, arsenic, zinc, and lead, are ubiquitously found in nature and, therefore, their contamination to milk and milk products must be considered [1]. Among these toxic metals, zinc is the most abundant one [8] and provided to humans. Although an adequate amount of zinc is physiologically important, exposure to the excess amount is harmful and toxic aspects of zinc arise [9]. Therefore, it becomes consumers' benefits to monitor whether the zinc concentration in milk or milk products is adequate or not.

Analytical methods towards hazardous chemical compounds in environments and foods have attracted much 
attention. Flame atomic absorption spectrometry (FAAS), electrothermal atomic absorption spectrometry (ET-AAS), inductively coupled plasma atomic emission spectroscopy (ICP-AES), inductively coupled plasma mass spectrometry (ICP-MS), hydride generation coupled with atomic absorption spectroscopy (HG-AAS) or atomic fluorescence spectroscopy (HG-AFS), X-ray spectroscopy, spectrofluorimetry, spectrophotometry, and electroanalytical techniques have been commonly used for determination and quantification of metals [9]. However, such standard methods require expensive and bulky laboratory equipments, analytical expertise and sample transportation, and generate hazardous wastes [10,11]. Expensive and bulky HG-AAS and HG-AFS have limits of detection (LODs) in the microgram per kilogram range [12] although ICP-AES sensitivity can be improved by coupling to HG. Under certain circumstances, sensing approaches with low cost can compete with traditional analyses in South-East Asia where contaminations by massive arsenic or other heavy metals in water or foods occur. In this sense, biosensors that measure bioavailable fractions of toxic metal ion have attracted much attention. To compensate the weaknesses of traditional methods, the biosensors that can detect As (III) and $\mathrm{Cd}$ (II)/Pb (II) $/ \mathrm{Zn}$ (II) in water have been developed using the trans factors/cis elements, ArsR/ars promoter-ars operator $\left(P_{\text {ars }}-O_{\text {ars }}\right)$ and $\mathrm{CadC} / \mathrm{cad}$ promoter-cad operator $\left(P_{\text {cad }}-O_{\text {cad }}\right)$ [13]. ArsR, encoded by arsR, binds exclusively to either $P_{\text {ars }}-O_{\text {ars }}$ or As (III), and CadC, encoded by $c a d C$, binds to either $P_{\text {cad }}-O_{\text {cad }}$ or $\mathrm{Cd}$ (II). The simple, inexpensive, and sensitive analysis of toxic metals in water was achieved by fusing ArsR or CadC to green fluorescent protein (ArsR-GFP or CadC-GFP). However, although different types of GFP-tagged biosensors have been developed for on-site determination of toxic metals in drinking water and soil extracts [13,14], these biosensors have not been tested for foods. Therefore, it remains unknown in milk and milk products whether these recombinant proteins keep their binding capabilities to metals or DNA and what amounts of toxic metals are quantified with previously established methods.

The aims of this study are to investigate responsiveness of trans factors that can bind to toxic metals or DNA in whole composition of cow's milk and yoghurt as well as in whey fractions and to develop simple methods for determination of toxic metals in the dairy products by application of the GFP-tagged trans factors and immobilized cis elements.

\section{Results}

\section{ArsR-GFP responds to externally added As (III)}

Only inorganic As (III) resulted in a decrease of fluorescence and no responses to inorganic As (V) and the organic forms of As such as methylarsonic acid, cacodylic acid, and arsenobetaine were observed [13,14]. Arsenic concentrations in milk were low and mostly in the form of trivalent inorganic arsenic [15]. Therefore, inorganic As (III) was taken under consideration in this study. Whole milk and yoghurt, to which As (III) was externally added, were fluorometrically tested with the assay using the separately prepared biosensor. The fluorescence response of ArsR-GFP to the As (III) within $40 \mathrm{~min}$ was analyzed in milk (Figure 1A and B) and yoghurt (Figure $1 \mathrm{C}$ and $\mathrm{D}$ ) with a microplate fluororeader (Figure $1 \mathrm{~A}$ and $\mathrm{C}$ ) and a portable fluorometer (Figure $1 \mathrm{~B}$ and $\mathrm{D}$ ). The results showed that fluorescence was significantly decreased at As (III) concentrations of $10-100 \mu \mathrm{g} / \mathrm{l}$ in milk and 10$100 \mu \mathrm{g} / \mathrm{kg}$ in yoghurt. The LODs for As (III) were determined to be $10 \mu \mathrm{g} / \mathrm{l}$ in milk and $10 \mu \mathrm{g} / \mathrm{kg}$ in yoghurt. The fluorescence intensities were linearly decreased with the increase in As (III) concentrations in milk $\left(R^{2}=0.979\right.$ and 0.988) (Figure 1A and B) and yoghurt $\left(R^{2}=0.924\right.$ and 0.934 ) (Figure $1 C$ and $D$ ). Using the separately prepared biosensors, the same LODs and working range for As (III) externally added to milk and yoghurt were reproduced (Additional file 1A and C). In measurement by ET-AAS, however, non-linearities were obtained between the As (III) concentrations added to milk or yoghurt and the absorbance values. Only $100 \mu \mathrm{g} / \mathrm{kg}$ As (III) was detected by ET-AAS (Table 1). The result shows that the specific protein-DNA and protein-metalloid interactions can be applied to quantification of the lower concentrations of As (III) in whole milk and yoghurt in comparison with ET-AAS.

\section{CadC-GFP responds to externally added Cd (II) but not to externally added $\mathrm{Pb}$ (II)}

Whole milk and yoghurt, to which $\mathrm{Cd}$ (II) or $\mathrm{Pb}$ (II) was externally added, were also tested with the separately prepared biosensor. Responses of CadC-GFP were analyzed in whole milk and yoghurt using a fluororeader and a portable fluorometer. CadC-GFP responded to $\mathrm{Cd}$ (II) dose-dependently at concentrations of 5-100 $\mu \mathrm{g} / \mathrm{l}$ in whole milk and $5-100 \mu \mathrm{g} / \mathrm{kg}$ in whole yoghurt when the fluorescence was measured by fluororeader and fluorometer (Figure 2). The LODs were $5 \mu \mathrm{g} / \mathrm{l}$ in whole milk and $5 \mu \mathrm{g} / \mathrm{kg}$ in whole yoghurt. The fluorescence was linearly decreased with the increase in $\mathrm{Cd}$ (II) concentrations in milk $\left(\mathrm{R}^{2}=0.982\right.$ and 0.977) (Figure 2A and $\mathrm{B}$ ) and yoghurt $\left(\mathrm{R}^{2}=0.753\right.$ and 0.813 ) (Figure $2 \mathrm{D}$ and $\mathrm{E}$ ). In measurement by ET-AAS, the linearity was obtained within a range of $0-100 \mu \mathrm{g} / \mathrm{kg}$ for milk $\left(R^{2}=0.957\right)$ and yoghurt $\left(R^{2}=0.992\right)$ (Figure $2 C$ and $\mathrm{F}$ ). The result shows that although the lower linearity is disadvantageous, almost same performance in terms of LOD as in ET-AAS is available in the fluorescent bioassay for Cd (II) in milk and yoghurt. Using the separately prepared biosensors, the same LODs and working range for $\mathrm{Cd}$ (II) in milk and yoghurt were 


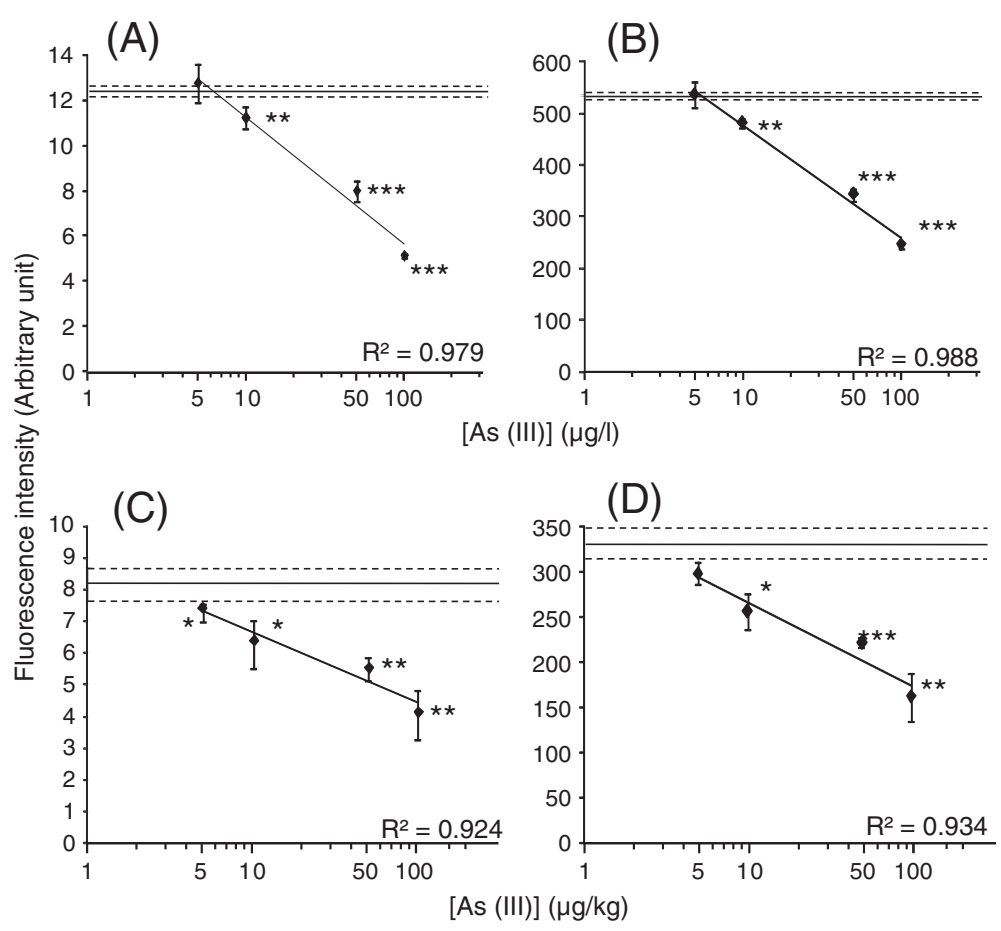

Figure 1 Fluorescence values arose from the ArsR-GFP associated with $P_{\text {ars }}-O_{\text {ars }}$ after incubation with As (III)-added milk (A and B) and yoghurt ( $C$ and $D)$ measured by fluororeader $(A$ and $C$ ) and fluorometer ( $B$ and $D)$. A solid line and two broken lines show mean \pm SD of data obtained with milk or yoghurt without addition of As (III). Asterisk means statistical significance versus the milk or yoghurt without addition of As (III) ( $\left.{ }^{*} P<0.05,{ }^{* *} P<0.01,{ }^{* * *} P<0.001\right)$.

reproduced (Additional file $1 \mathrm{~B}$ and $\mathrm{D}$ ). On the other hand, the fluorescent intensity of CadC-GFP significantly decreased at $5 \mu \mathrm{g} / \mathrm{l} \mathrm{Pb}$ (II) in milk and $100 \mu \mathrm{g} / \mathrm{kg}$ $\mathrm{Pb}$ (II) in yoghurt. However, lower reduction of fluorescence intensity and lower linearity of the response were found within the tested range (Figure 3). Therefore, CadC-GFP might not be suitable for measurement of $\mathrm{Pb}$ (II) using whole products. The fluorescence decreases at each concentration were more marked in Cd (II) than in $\mathrm{Pb}$ (II) in the assays.

\section{CadC-GFP responds to $\mathrm{Zn}$ (II) extracted into whey} fractions but not to $\mathrm{Zn}$ (II) in whole composition Whole milk and yoghurt, to which Zn (II) was externally added, were tested with the separately prepared biosensor. The significant responses of CadC-GFP to externally added $\mathrm{Zn}$ (II) were observed at $10 \mu \mathrm{g} / \mathrm{l}$ for whole milk (Figure $4 \mathrm{~A}$ and B) and 50 or $10 \mu \mathrm{g} / \mathrm{kg}$ for whole yoghurt (Figure $4 \mathrm{C}$ and D). The linearity was obtained within a range of $5-100 \mu \mathrm{g} / \mathrm{l}$ for milk $\left(R^{2}=0.895\right.$ and 0.916$)$ and within a range of $5-100 \mu \mathrm{g} / \mathrm{kg}$ for yoghurt $\left(R^{2}=0.997\right.$ and 0.983). However, as observed in the fluorescence responses to externally added $\mathrm{Pb}$ (II), low reduction of fluorescence intensity was found in response to externally added Zn (II) concentrations in milk and yoghurt. It has been reported that zinc in milk usually binds to the low molecular weight ligands as citrate and amino acids, and to proteins such as casein, $\alpha$-lactalbumin, and lactoferrin $[16,17]$. It was expected that externally added $\mathrm{Pb}$ (II) or $\mathrm{Zn}$ (II) in whole milk and yoghurt might bind to the low molecular weight ligands or the milk proteins strongly. It has been reported that lowering $\mathrm{pH}$ of cow's

Table 1 Analytical performance of the biosensors compared with those of ICP-AES and ET-AAS

\begin{tabular}{|c|c|c|c|c|c|c|c|c|}
\hline & \multicolumn{4}{|c|}{ Biosensors } & \multicolumn{4}{|c|}{ Traditional analytical method ${ }^{1}$} \\
\hline & \multicolumn{2}{|c|}{ LOD } & \multicolumn{2}{|c|}{ Detection range } & \multicolumn{2}{|c|}{ LOD } & \multicolumn{2}{|c|}{ Detection range } \\
\hline & $\begin{array}{c}\text { Milk } \\
(\mu \mathrm{g} / \mathrm{l})\end{array}$ & $\begin{array}{l}\text { Yoghurt } \\
(\mu \mathrm{g} / \mathrm{kg})\end{array}$ & $\begin{array}{l}\text { Milk } \\
(\mathrm{mg} / \mathrm{l})\end{array}$ & $\begin{array}{l}\text { Yoghurt } \\
\text { (mg/kg) }\end{array}$ & $\begin{array}{c}\text { Milk } \\
(\mu \mathrm{g} / \mathrm{kg})\end{array}$ & $\begin{array}{l}\text { Yoghurt } \\
(\mu \mathrm{g} / \mathrm{kg})\end{array}$ & $\begin{array}{c}\text { Milk } \\
(\mathrm{mg} / \mathrm{kg})\end{array}$ & $\begin{array}{l}\text { Yoghurt } \\
\text { (mg/kg) }\end{array}$ \\
\hline External As (III) & \multicolumn{2}{|c|}{10} & \multicolumn{2}{|c|}{$10-100$} & \multicolumn{2}{|c|}{100} & \multicolumn{2}{|c|}{100} \\
\hline External Cd (II) & \multicolumn{2}{|c|}{5} & \multicolumn{2}{|c|}{$5-100$} & & & \multicolumn{2}{|c|}{$5-100$} \\
\hline Intrinsic Zn (II) & & & $1.4-4.8$ & $1.2-2.9$ & & & $1.4-2.4$ & $2.5-4.7$ \\
\hline
\end{tabular}

${ }^{1}$ ET-AAS and ICP-AES were used for measurement of externally added As (III)/Cd (II) and intrinsic Zn (II), respectively. 


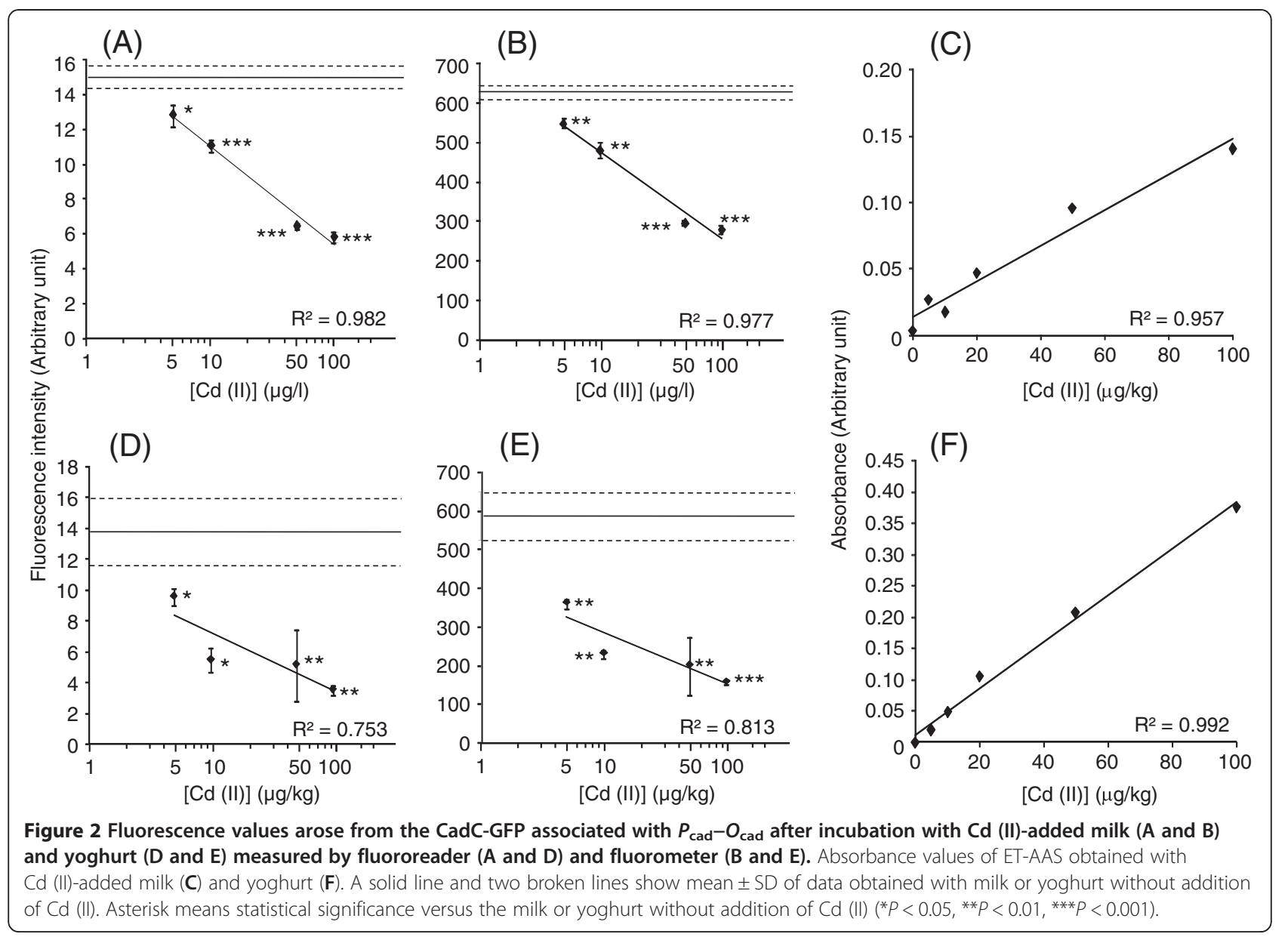

milk changed zinc and protein distribution and resulted in the shift of zinc from pellet (casein) to whey [16]. Therefore, pre-treatments for milk and yoghurt were considered. Firstly, $\mathrm{pH}$ of whole milk was lowered to 4.6 or below to change zinc and protein distribution and extract zinc from pellet into whey. Secondly, in order to reduce concentrations of substances in the whey fractions of yoghurt or acid-treated milk, 100-times dilution was performed with sterilized ultrapure water. The previous analysis concerning the CadC-GFP specificity revealed the enhancement of its background fluorescence by $\mathrm{Ca}$ [13]. Milk or yoghurt usually contains abundant elements such as $\mathrm{Ca}, \mathrm{P}, \mathrm{Mg}$, $\mathrm{Na}$, and $\mathrm{Zn}$. Therefore, an excess amount of Ca (II) (10 mg/l) was externally added to $\mathrm{Zn}$ (II) standard solutions so that the effect of intrinsic Ca (II) in the diluted whey fractions on the background fluorescence was eliminated. The $\mathrm{pH}$ of standard solutions was adjusted to an average $\mathrm{pH}$ of tested whey fractions. Fluorescence intensities of CadC-GFP bound to $P_{\text {cad }}-O_{\text {cad }}$ after incubation with whey fractions from different brands of milk (Additional file 2a-c) and yoghurt (Additional file $2 \mathrm{~d}-\mathrm{g}$ ) were measured using a portable fluorometer. The fluorescence intensities decreased in the separately prepared biosensor with increasing concentration of $\mathrm{Zn}$ (II) in the standard solutions (Additional file 2). This can be explained by an assumption that, in this assay, the fluorescence arises from the CadC-GFP associated with $P_{\text {cad }}-O_{\text {cad }}$ and the association constant between CadCGFP and $P_{\text {cad }}-O_{\text {cad }}$ decreases in the presence of $\mathrm{Zn}$ (II). Besides this, CadC-GFP also responded to whey fractions derived from different brands of milk (Additional file $3 a-c$ ) and yoghurt (Additional file $3 d$ and e) using the solid phase biosensor. Fluorescence intensities increased in response to $\mathrm{Zn}$ (II) in the standard solutions (Additional file 3). In this assay, the fluorescence arises from the CadC-GFP dissociated from $P_{\text {cad }}-O_{\text {cad }}$ and the dissociation constant between CadC-GFP and $P_{\text {cad }}-O_{\text {cad }}$ might increase in response to $\mathrm{Zn}$ (II) [14]. Measurement of $\mathrm{Zn}$ (II) concentrations in the whey fractions was repeated in different batches (Additional files 2 and 3). The concentrations of different brand of milk and yoghurt determined using the separately prepared biosensor varied from 1.5 to $4.8 \mathrm{mg} / \mathrm{l}$ and 1.8 to $2.9 \mathrm{mg} / \mathrm{kg}$, respectively. When those were determined using the solid phase biosensor, 1.4 to $3.3 \mathrm{mg} / \mathrm{l}$ for milk 


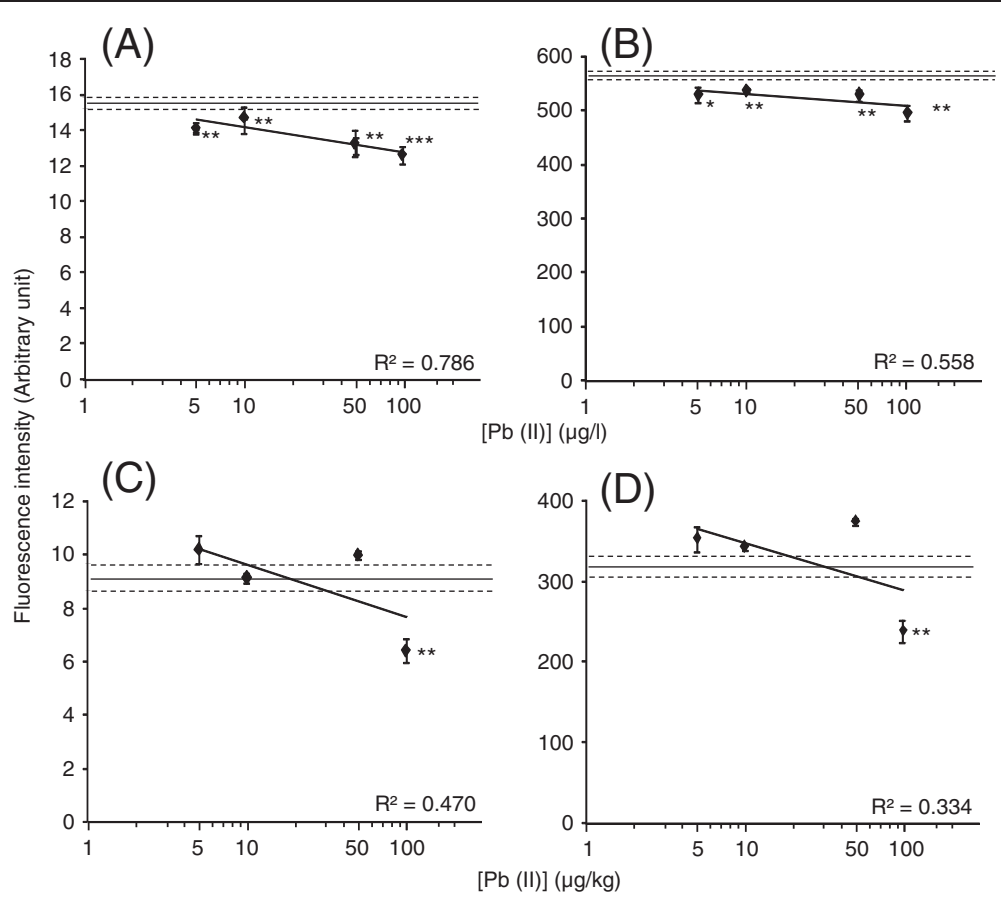

Figure 3 Fluorescence values arose from the CadC-GFP associated with $P_{\text {cad }}-O_{\text {cad }}$ after incubation with Pb (II)-added milk (A and B) and yoghurt ( $C$ and $\mathbf{D})$ measured by fluororeader $(\mathbf{A}$ and $\mathbf{C})$ and fluorometer $(\mathbf{B}$ and $\mathbf{D})$. A solid line and two broken lines show mean \pm SD of data obtained with milk or yoghurt without addition of Pb (II). Asterisk means statistical significance versus the milk or yoghurt $\mathrm{t}$ without addition of $\mathrm{Pb}(\mathrm{II})\left({ }^{*} P<0.05,{ }^{* *} P<0.01,{ }^{* *} P<0.001\right)$.

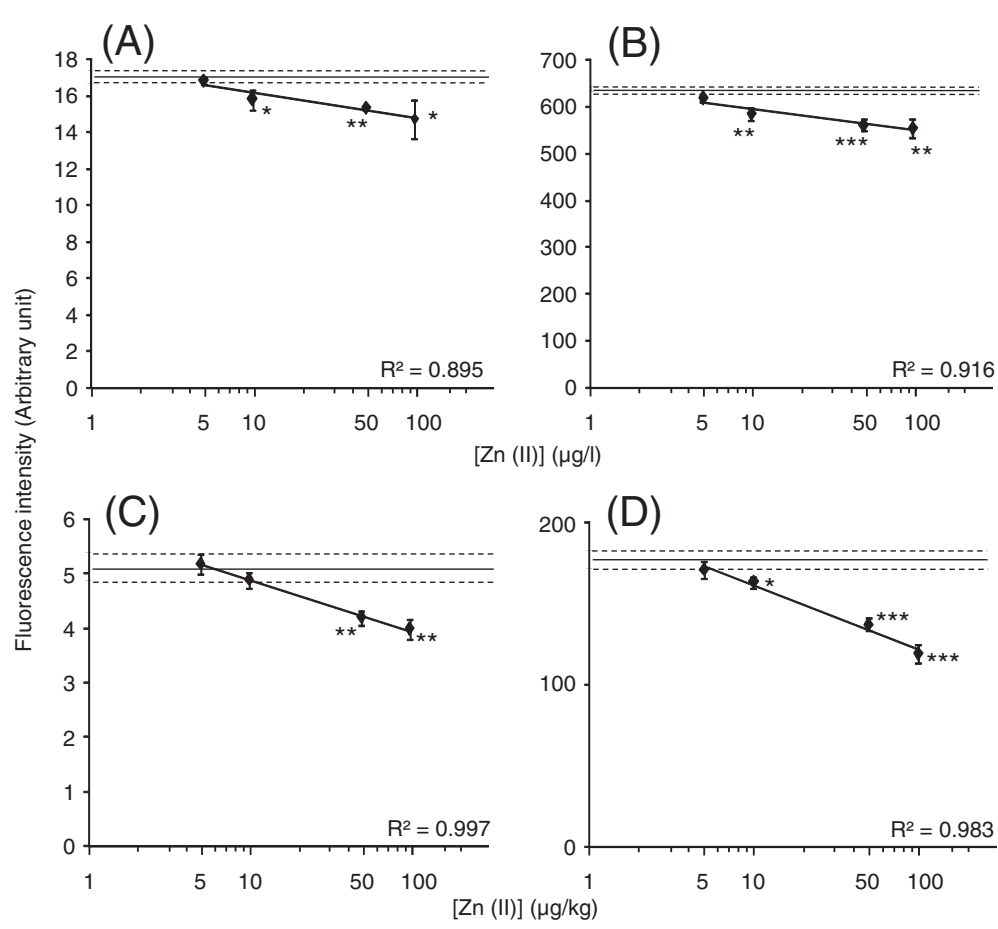

Figure 4 Fluorescence values arose from the CadC-GFP associated with $P_{\text {cad }}-O_{\text {cad }}$ after incubation with $\mathrm{Zn}$ (II)-added milk (A and B) and yoghurt ( $C$ and $\mathbf{D})$ measured by fluororeader ( $A$ and $C$ ) and fluorometer (B and $D)$ ). A solid line and two broken lines show mean \pm SD of data obtained with milk or yoghurt without addition of $\mathrm{Zn}$ (II). Asterisk means statistical significance versus the milk or yoghurt $\mathrm{t}$ without addition of $\mathrm{Zn}(\mathrm{II})\left({ }^{*} P<0.05,{ }^{* *} P<0.01,{ }^{* * *} P<0.001\right)$. 
and 1.2 to $2.5 \mathrm{mg} / \mathrm{kg}$ for yoghurt were obtained. These $\mathrm{Zn}$ (II) concentrations overlapped with the reported ranges of zinc content, which varied from 0.29 to $4.96 \mu \mathrm{g} / \mathrm{g}$ in raw bovine milk [5] and from 2.19 to $4.85 \mu \mathrm{g} / \mathrm{g}$ in yoghurt [18]. The result suggests that the pre-treatments and fluorescence measurements are adequate and reproducible in determination of $\mathrm{Zn}$ (II) concentrations.

\section{Correlation between zinc contents measured with the bioassays and ICP-AES}

The Zn (II) contents were determined towards the whey fractions in the bioassays. In order to evaluate whether or not the bioassays are available as simple and on-site protocols to measure zinc content in milk or yoghurt, zinc in whole milk or yoghurt was quantified with a standard protocol, ICP-AES. Then, correlations between the $\mathrm{Zn}$ (II) contents in whey fractions and the zinc contents in whole products were evaluated. Positive and linear correlations were found in the separately prepared biosensor for milk (Figure 5A) and yoghurt (Figure 5C). When bioassay was performed using the solid phase biosensor, the correlation coefficients for milk and yoghurt were smaller than those obtained with the separately prepared biosensor (Figure $5 \mathrm{~B}$ and $\mathrm{D}$ ). Although, the data obtained with biosensor and ICP-AES were not highly correlated, those were plotted within narrow concentration ranges of 1.3 to $4.8 \mathrm{mg} / \mathrm{l}$ or $\mathrm{mg} / \mathrm{kg}$ for milk and 1.1 to $4.7 \mathrm{mg} / \mathrm{kg}$ for yoghurt. Therefore, both types of biosensor could detect an unexpected or abnormal value in routine monitoring of $\mathrm{Zn}$ (II) for milk and yoghurt with a simple protocol and a handheld device.

\section{Discussion}

The bioassays to quantify toxic metals can even compensate with expensive instrumental analyses such as AAS, ICP, and AFS. For traditional analytical techniques such as ICP-AES and ET-AAS, dry mineralization or microwave-induced combustion methods are generally essential for quantitative extraction of toxic metals from samples. Contrary to necessity of these time-consuming pre-treatments, toxic metals in milk and yoghurt could be measured directly or only with preparation of whey and dilution in the fluorescent bioassays. The simple pre-treatment for the fluorescent bioassays was required to prepare transparent samples because the samples were loaded into the solid phase biosensors and provided directly to fluorescence measurement. It has been reported that casein was precipitated at $\mathrm{pH} 4.6$ and about $90 \%$ of the zinc content and $95 \%$ of the citrate content identified as zinc citrate were released into the whey fraction [19]. This knowledge supports the results obtained in this study that zinc concentrations in whey fractions measured by biosensors correlated with those
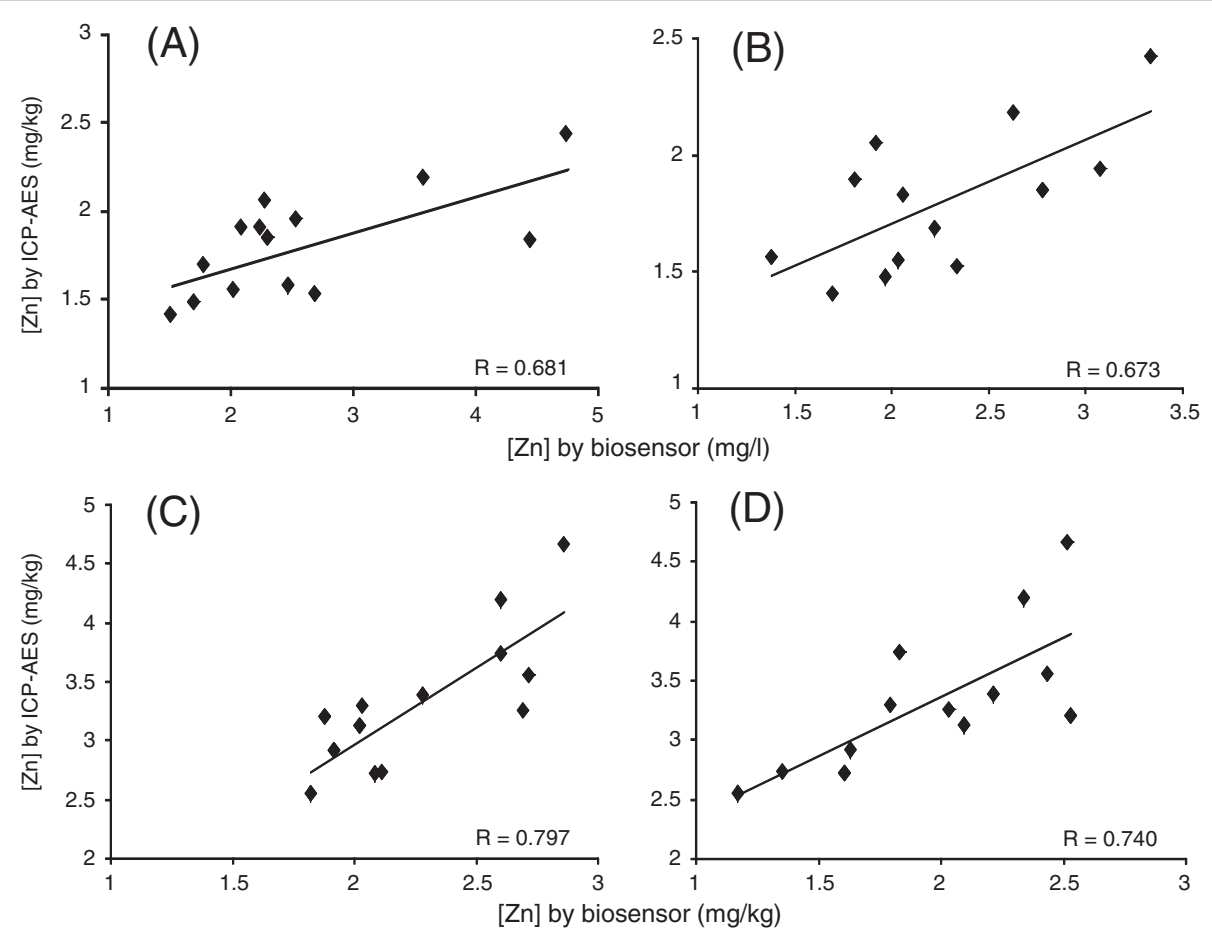

Figure 5 Correlations between $\mathrm{Zn}$ (II) concentrations in the whey fractions prepared from milk (A and B) or yoghurt (C and D) and zinc concentrations in whole milk or yoghurt determined with ICP-AES. The separately prepared biosensor ( $\mathbf{A}$ and $\mathbf{C}$ ) and solid phase biosensor (B and $\mathbf{D})$ were used. The correlation coefficient $(\mathrm{R})$ is shown in each panel. 
in whole milk measured by ICP-AES. The analytical performances of the biosensors, ICP-AES, and ET-AAS were summarized (Table 1). The reported ranges of arsenic, cadmium, and zinc are 0.001-0.15, 0.070-0.112, and $3.001-3.940 \mathrm{mg} / \mathrm{kg}$ in milk, and $0.01-0.35,0.059$, and $2.638 \mathrm{mg} / \mathrm{kg}$ in yoghurt $[8,12]$. Using the bioassays developed in this study, $0.01-0.1 \mathrm{mg} / \mathrm{kg}$ As (III), $0.005-$ $0.1 \mathrm{mg} / \mathrm{kg}$ Cd (II) could be quantified in milk and yoghurt. The ranges of $1.4-4.8 \mathrm{mg} / \mathrm{l}$ of intrinsic $\mathrm{Zn}$ (II) in milk and 1.2-2.9 $\mathrm{mg} / \mathrm{kg}$ for yoghurt were determined using commercially available brands. Therefore, it is likely that the biosensors harbour practically available ranges of detection for As (III), Cd (II), and Zn (II).

The GFP-tagged trans factors responded to several metals and metalloids. Among these elements, the responses and sensitivities to Sb (III) were lower than those to other toxic metals [13]. Pb (II) or $\mathrm{Zn}$ (II) in whole milk and yoghurt bound to the low molecular weight ligands or the milk proteins strongly so that CadC-GFP could not respond to these metals sufficiently. Therefore, specificity to As (III) or Cd (II) in the direct bioassay using whole milk and yoghurt would be expected. It has been reported that, among heterogeneous elements generally contained in milk and yoghurt, $\mathrm{Ca}$ (II) and $\mathrm{Mg}$ (II) affected fluorescence intensity of ArsR-GFP and CadC-GFP [13]. Therefore, it remains to be clarified before practical use whether the fluorescence intensity is affected by $\mathrm{Ca}$ (II) and $\mathrm{Mg}$ (II) when As (III) or Cd (II) would be quantified directly using whole milk and yoghurt. It is also important to prepare standard solution or whole product that could control fluorescence intensity as a background.

The toxic metal biosensors have been developed based on interactions between GFP-tagged trans factors and immobilized cis elements. In addition to the biosensors composed of protein and DNA, a large number of recombinant whole-cell sensors that utilize the sensitivity and selectivity of trans factors have been reported. Practical advantages of such biosensor in respect of portability, cost, and manipulation were shown in monitoring drinking and environmental water when it was compared to conventional analytical instruments. However, recombinant whole-cell sensors that could work under nutrient-rich and not defined conditions, as in milk and yoghurt, had not been established. It is expected that whole-cell sensors that can detect $\mathrm{Zn}$ (II) in nutrientpoor water might not work in milk and dairy products because carbon sources and other nutrients must affect their metabolisms and cell growth. Even though conventional analytical instruments would be used, extraction techniques of zinc from milk and dairy products will be required prior to measurement as shown previously [9]. Considering such complexity, it is quite advantageous that the elements of biosensor can work in the whole products towards As (III) and Cd (II) as well as in the whey fractions obtained with extraction towards $\mathrm{Zn}$ (II). The isolation of trans factors and cis elements from bacterial cells enabled application of transcriptional switches to sensing toxic metals in the dairy products. To our knowledge, the assays developed in this study are the first one that could quantify toxic metals in milk and yoghurt using biosensing elements.

\section{Conclusions}

Interactions between GFP-tagged trans factor and cis element could be effectively applied to measurement of As (III), Cd (II), and Zn (II) in milk or yoghurt. Fluorescence intensities obtained with the separately prepared biosensors, which arose from the associated protein, decreased significantly with increasing concentrations of the toxic metals, whereas fluorescence intensities with the solid phase biosensors, which arose from the dissociated protein, increased in response to $\mathrm{Zn}$ (II). The GFP-tagged proteins were able to respond to As (III) within ranges of $10-100 \mu \mathrm{g} / \mathrm{l}$ in milk and $10-100 \mu \mathrm{g} / \mathrm{kg}$ in yoghurt and $\mathrm{Cd}$ (II) within ranges of $5-100 \mu \mathrm{g} / \mathrm{l}$ in milk and 5-100 $\mu \mathrm{g} / \mathrm{kg}$ in yoghurt. However, lower reduction of fluorescence response was obtained towards $\mathrm{Pb}$ (II) and $\mathrm{Zn}$ (II). Therefore, the optimized pre-treatments, which were lowering $\mathrm{pH}$ and 100-times dilution of the obtained whey fractions, were important for measuring $\mathrm{Zn}$ (II) in milk and yoghurt. Positive correlations were found between $\mathrm{Zn}$ (II) determined with the separately prepared biosensor or solid phase biosensor and total zinc determined with ICP-AES. Thus, the interaction between trans factor and cis element could be utilized to simple quantification of toxic metals in milk and yoghurt that protects us from excessive and chronic exposure to them.

\section{Methods \\ Preparation of cell lysates containing GFP-tagged trans factor}

An $\operatorname{ars} R$ gene encoding the As (III)-binding regulatory protein originated from Escherichia coli K12 DNA and a cadC gene encoding the $\mathrm{Cd}$ (II)/Pb (II)/Zn (II)-binding regulatory protein from Staphylococcus aureus NCTC50581 plasmid pI258 have been fused to a structural gene for the green fluorescent protein (AcGFP1) to produce ArsR-GFP and CadC-GFP, as described previously [13]. Recombinant E. coli strains were grown in Luria-Bertani (LB) medium supplemented with ampicillin $(50 \mu \mathrm{g} / \mathrm{ml})$ and chloramphenicol $(34 \mu \mathrm{g} / \mathrm{ml})$ at $25^{\circ} \mathrm{C}$ for $24 \mathrm{~h}$ with $120 \mathrm{rpm}$ in reciprocating shaker. Cell lysate containing either ArsR-GFP or CadC-GFP was prepared from the cultures containing $2 \times 10^{9}$ cells $/ \mathrm{ml}$ as described previously [13]. 


\section{Preparation and immobilization of promoter-operator DNA}

The double-stranded ars promoter-ars operator, $P_{\text {ars }}-O_{\text {ars }}$, and the cad promoter-cad operator, $P_{\text {cad }}-O_{\text {cad }}$, were prepared by mixing either $P_{\text {ars }}-O_{\text {ars }}-50$ or $P_{\text {cad }}-O_{\text {cad }}-50$, whose $3^{\prime}$ end was modified with biotin, and their complimentary oligonucleotide [13] at $50 \mu \mathrm{M}$, denaturing at $94^{\circ} \mathrm{C}$ for $2 \mathrm{~min}$, and cooling down to room temperature. The double-stranded DNA fragments in $25 \mathrm{mM}$ Tris- $\mathrm{HCl}$ buffer $\mathrm{pH} 7.4$ were immobilized at a concentration of $30 \mathrm{pmol} / 50 \mu \mathrm{l} P_{\text {ars }}-O_{\text {ars, }}$, or $25 \mathrm{pmol} /$ $50 \mu \mathrm{l} P_{\text {cad }}-O_{\text {cad }}$ onto a Reacti-bind streptavidin-coated high binding capacity black 96-well microplate (Thermo Fisher Scientific, Yokohama, Japan) as described previously [13]. After the incubation, excess unbound DNA was rinsed off 3 times by $25 \mathrm{mM}$ Tris- $\mathrm{HCl}(\mathrm{pH} 7.4)$ buffer.

\section{Addition of toxic metals to milk and yoghurt}

Standard solutions of As (III), Cd (II), Zn (II), and $\mathrm{Pb}$ (II) were prepared by dissolving $\mathrm{NaAsO}_{2}, \mathrm{CdCl}_{2} \cdot 2.5 \mathrm{H}_{2} \mathrm{O}$ (both from Sigma-Aldrich, Tokyo, Japan), $\mathrm{ZnSO}_{4} \cdot 7 \mathrm{H}_{2} \mathrm{O}$, and $\mathrm{Pb}\left(\mathrm{C}_{2} \mathrm{H}_{3} \mathrm{O}_{2}\right)_{2} \cdot 3 \mathrm{H}_{2} \mathrm{O}$ (both from Wako Pure Chemical, Osaka, Japan) in ultrapure water (Simplicity UV, Millipore-Japan, Tokyo). Milk and yoghurt were collected from local supermarket at Utsunomiya, Japan and stored at $7^{\circ} \mathrm{C}$. Milk was fortified with $5,10,50$, and $100 \mu \mathrm{g} / \mathrm{l}$ of As (III), Cd (II), Pb (II), or Zn (II) and homogenized properly (Figure 6A). Yoghurt was also fortified with the same concentrations per $\mathrm{kg}$, and then, $\mathrm{pH}$ of yoghurt sample was adjusted to $7.0 \pm 0.2$ before assay because yoghurt itself is acidic and it hampers biosensing.

\section{Pre-treatments of milk and yoghurt to prepare whey fractions for $\mathrm{Zn}$ measurement}

For milk, $10.0 \mathrm{ml}$ was sampled and its $\mathrm{pH}$ was lowered to 4.6 or below (Figure 6). For yoghurt, $0.50 \mathrm{~g}$ was taken and diluted 100 times with ultrapure water. Then, the $\mathrm{pH}$ lowered milk and diluted yoghurt were incubated for 30 min to allow zinc shift from curd to whey and finally centrifuged for $30 \mathrm{~min}$ at $4^{\circ} \mathrm{C}$ and $10,000 \times g$. The whey fractions were collected in sterile tubes and used for biosensing. Prior to biosensing, the whey fractions obtained from milk were diluted 100 times to decrease Zn (II) concentration.

\section{Measurement of arsenic and cadmium by AAS and zinc by ICP-AES}

All glassware and crucibles were cleaned by soaking with $0.5 \mathrm{~N} \mathrm{HNO}_{3}$ overnight and rinsed several times with deionized water and dried prior to use.

For arsenic and cadmium measurement by ET-AAS, milk and yoghurt were digested by microwave-induced combustion methods. Whole milk and yoghurt were fortified with $5,10,20,50$, and $100 \mu \mathrm{g} / \mathrm{l}$ of As (III) or Cd (II). After homogenization, $5.00 \pm 0.01 \mathrm{~g}$ of milk or yoghurt was weighed and poured in teflon microwave digestion vessel. Five milliliters of $50 \%(\mathrm{v} / \mathrm{v}) \mathrm{HNO}_{3}$ and $2 \mathrm{ml}$ $30 \%(\mathrm{v} / \mathrm{v}) \mathrm{H}_{2} \mathrm{O}_{2}$ were added to the sample mixtures in digestion vessels. The vessels were closed and fastened in the rotor, and placed into the microwave-induced digestion
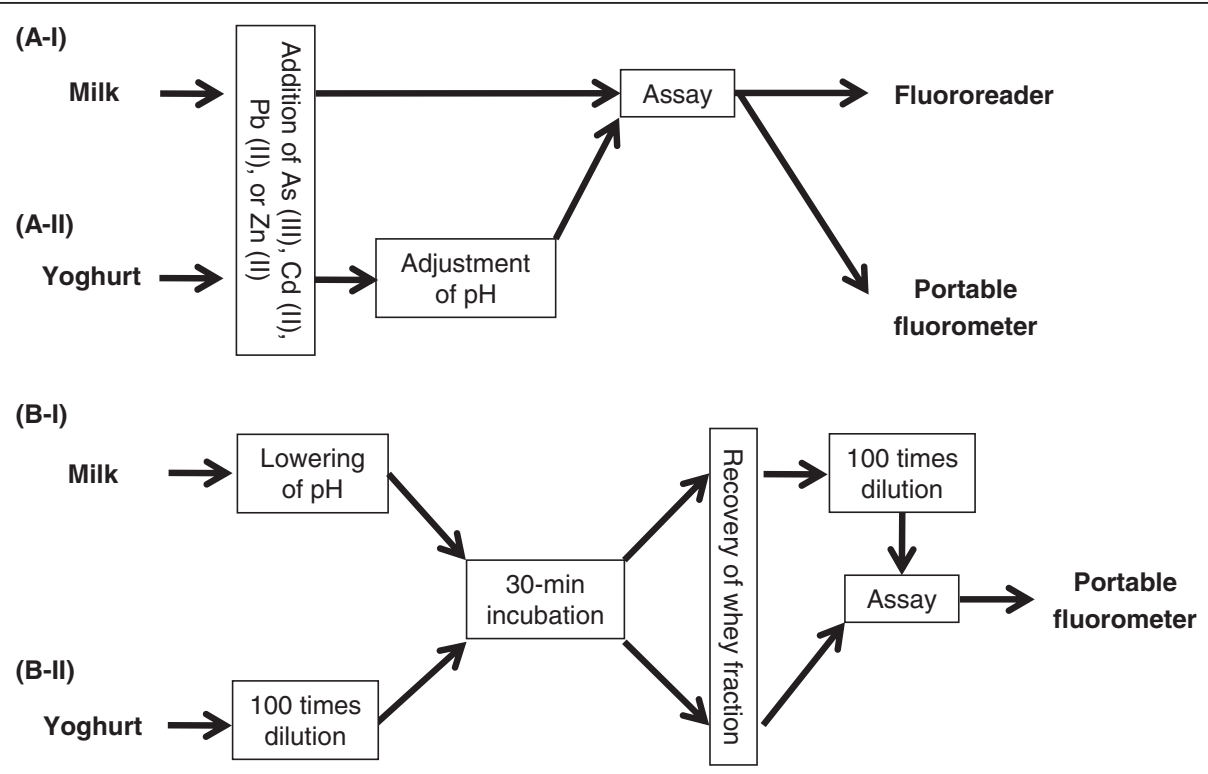

Figure 6 Schematic representation of milk and yoghurt sample preparation for bioassays. Preparation of milk (A-I) and yoghurt (A-II) that includes externally added toxic metal for bioassays with whole products. Pre-treatments for milk (B-I) and yoghurt (B-II) to prepare their whey fractions for Zn (II) bioassays. 
device (ETHOS-900, Milestone-general, Kawasaki, Japan). A microwave digestion program applied was $250 \mathrm{~W}$ for $1 \mathrm{~min}, 0 \mathrm{~W}$ for $1 \mathrm{~min}, 250 \mathrm{~W}$ for $5 \mathrm{~min}, 400 \mathrm{~W}$ for $5 \mathrm{~min}$, and $650 \mathrm{~W}$ for $5 \mathrm{~min}$. After digestion, all the mixtures were evaporated. The dried residues were recovered by $5 \mathrm{ml}$ each of $0.5 \mathrm{~N} \mathrm{HCl}$. The concentrations of As (III) and Cd (II) were determined by ET-AAS (Z-5010, Hitachi high-technologies, Tokyo, Japan).

An ashing aid suspension was prepared at concentrations of $100 \mathrm{~g} / \mathrm{l} \mathrm{Mg}\left(\mathrm{NO}_{3}\right)_{2} \cdot 6 \mathrm{H}_{2} \mathrm{O}$ and $10 \mathrm{~g} / \mathrm{l} \mathrm{MgO}$ (both from Sigma-Aldrich) using ultrapure water. After homogenization, $5.00 \pm 0.01 \mathrm{~g}$ of whole milk or yoghurt was weighed and poured into a porcelain crucible for zinc measurement. The milk or yoghurt portion was homogenized again after adding $0.25 \mathrm{ml}$ of the ashing aid suspension to improve decomposition of the organic matrix, and evaporated to near dryness at $105^{\circ} \mathrm{C}$ in an oven. Two milliliters each of $50 \%(\mathrm{v} / \mathrm{v}) \mathrm{HNO}_{3}$ was added to the oven dried residues and the mixtures were dried off on a hotplate. Then, the residues were heated in an electric muffle furnace (FUW 220PA, Advantec, Tokyo, Japan) at atmospheric pressure using the following heating program: $150^{\circ} \mathrm{C}$ for $1 \mathrm{~h}, 200^{\circ} \mathrm{C}$ for $2 \mathrm{~h}, 250^{\circ} \mathrm{C}$ for $1 \mathrm{~h}$, $300^{\circ} \mathrm{C}$ for $3 \mathrm{~h}, 350^{\circ} \mathrm{C}$ for $30 \mathrm{~min}, 400^{\circ} \mathrm{C}$ for $30 \mathrm{~min}$, and finally $450^{\circ} \mathrm{C}$ for $14 \mathrm{~h}$ [20]. One milliliter each of $50 \%$ $(\mathrm{v} / \mathrm{v}) \mathrm{HNO}_{3}$ was added to the grey residues in crucibles and the mixtures were dried off on a hotplate. Then, the residues were reheated in a muffle furnace using the same temperature-time program as shown above. The crucibles containing white ashes were removed from the muffle furnace and cooled to room temperature. The white ashes were dissolved in $5 \mathrm{ml}$ each of $0.5 \mathrm{~N} \mathrm{HCl}$ and the solutions in the crucibles were transferred to clean glass tubes. The concentrations of $\mathrm{Zn}$ (II) in the solutions were determined by inductively coupled plasma-atomic emission spectrometry (ICP-AES) (ICPS-7500, Shimadzu, Kyoto, Japan). Measurement was repeated 3 times for each sample.

\section{Quantification of metals by the separately prepared biosensors}

The separately prepared biosensors, which were based on interaction between CadC-GFP and $P_{\text {cad }}-O_{\text {cad }}$ or between ArsR-GFP and $P_{\text {ars }}-O_{\text {ars }}$, were applied to measurements of externally added As (III), Cd (II), Pb (II), and $\mathrm{Zn}$ (II) in whole milk or yoghurt. For the As (III) assay, 93 volumes of whole milk/yoghurt or whey fraction was mixed with 5 volumes of $1 \mathrm{M}$ potassium phosphate buffer (KPB) pH6.7, 0.5 volumes of $10 \mathrm{mg} / \mathrm{ml}$ salmon sperm DNA, 1 volume of $4 \mathrm{M} \mathrm{NaCl}$, and 0.5 volumes of ArsR-GFP (final concentrations; $50 \mathrm{mM}$ KPB pH6.7, $50 \mu \mathrm{g} / \mathrm{ml}$ salmon sperm DNA, $40 \mathrm{mM}$ $\mathrm{NaCl}$, approximately $20 \mu \mathrm{g} / \mathrm{ml}$ ArsR-GFP). For the $\mathrm{Cd}$ (II), $\mathrm{Pb}$ (II), and $\mathrm{Zn}$ (II) assay, the milk/yoghurt or whey fraction was mixed with the same composition except for that $1 \mathrm{M}$ Tris-HCl $\mathrm{pH} 7.4$ and CadC-GFP were used instead of $1 \mathrm{M} \mathrm{KPB} \mathrm{pH6.7} \mathrm{and} \mathrm{ArsR-GFP.}$ The ArsR-GFP or CadC-GFP mixture was preincubated at room temperature for $15 \mathrm{~min}$ and $100 \mu \mathrm{l}$ aliquots were poured on the wells of microplate, on which $P_{\text {cad }}-O_{\text {cad }}$ or $P_{\text {ars }}-O_{\text {ars }}$ was immobilized. Then, the microplate was incubated for $15 \mathrm{~min}$ with orbital shaking at $120 \mathrm{rpm}$, and supernatants were removed from the wells. The wells were once washed off with $200 \mathrm{\mu l}$ KP-T buffer $(10 \mathrm{mM}$ potassium phosphate $\mathrm{pH6.0,0.05 \%} \mathrm{(wt/vol)} \mathrm{Tween20),} \mathrm{and} 150 \mu \mathrm{l}$ of measuring buffer $(20 \mathrm{mM}$ Tris- $\mathrm{HCl}$ pH7.9, $1.0 \mathrm{M} \mathrm{NaCl}$, and $0.10 \%$ (wt/vol) Tween20) was added. After incubation for $5 \mathrm{~min}$ to dissociate proteins from the surface of wells, the supernatants were transferred to wells of another black plate or glass vessels. Fluorescence in the wells was measured with a microplate fluororeader (MTP-601, Hitachi High Technologies, Tokyo, Japan) at excitation/emission wavelengths of $490 / 530 \mathrm{~nm}$. A glass vessel prepared from the assay was inserted to an excitation/detection hole of a handheld, batterypowered portable fluorometer (GFP-pen GFP 100, Photon systems instruments, Brno, Czech Republic). After insertion of the vessel, the hole was shaded by a black polyurethane closure and fluorescence from the supernatant was measured. Measurement was repeated three times per vessel. Student's $t$-test was used to evaluate probability within two groups including data obtained with ultrapure water. Metal concentrations were plotted on a logarithmic scale against fluorescence intensities to evaluate linearity of florescence response.

\section{Quantification of $\mathrm{Zn}$ (II) by the solid phase biosensor}

$\mathrm{Zn}$ (II) in the prepared whey could be quantified with the solid phase biosensor. In this assay, the number of steps was reduced by directly adding whey fractions to the wells whose surface was modified with a complex of CadC-GFP and immobilized $P_{\text {cad }}-O_{\text {cad }}$ [14]. The CadC-GFP mixture was prepared at final concentrations of $50 \mathrm{mM}$ Tris- $\mathrm{HCl}$ buffer $\mathrm{pH} 7.4,50 \mu \mathrm{g} / \mathrm{ml}$ salmon sperm DNA, $40 \mathrm{mM} \mathrm{NaCl}$, and approximately $20 \mu \mathrm{g} / \mathrm{ml}$ CadC-GFP. Then, $100 \mu \mathrm{l}$ of the CadC-GFP mixture was poured to each well, in which $P_{\text {cad }}-O_{\text {cad }}$ was immobilized, and allowed 15-min incubation. The wells were once washed off with $200 \mu \mathrm{l} \mathrm{KP-T}$ buffer. For Zn (II) assay, 93.5 volumes of prepared whey fraction was mixed with 5 volumes of $1 \mathrm{M}$ Tris- $\mathrm{HCl} \mathrm{pH} 7.9,0.5$ volumes of $10 \mathrm{mg} / \mathrm{ml}$ salmon sperm DNA and 1 volume of $4 \mathrm{M}$ $\mathrm{NaCl}$ (final concentrations; $50 \mathrm{mM}$ Tris- $\mathrm{HCl}, 50 \mu \mathrm{g} / \mathrm{ml}$ salmon sperm DNA, $40 \mathrm{mM} \mathrm{NaCl}$ ). One hundred five microliters of sample mixture were added to each well, and incubated for $15 \mathrm{~min}$ with orbital shaking at $120 \mathrm{rpm}$ to make $\mathrm{Zn}$ (II)-bound CadC-GFP release from 
immobilized $P_{\text {cad }}-O_{\text {cad }}$. Fluorescence of CadC-GFP was measured as described above. $\mathrm{Zn}$ (II) concentrations in standard solution were plotted on a logarithmic scale against fluorescence intensities to make a standard curve. $\mathrm{Zn}$ (II) concentrations in milk and yoghurt were determined by using the standard curves and multiplying the dilution factor.

\section{Additional files}

Additional file 1: Reproducibility of bioassays using the separately prepared biosensors for milk ( $A$ and $B$ ) and yoghurt ( $C$ and $D)$.

Additional file 2: Fluorescence data in bioassays for the whey fractions prepared from different brands of milk (a-c) and yoghurt (d-g) using the separately prepared biosensor (CadC-GFP and $\left.P_{\text {cad }}-O_{\text {cad }}\right)$ and fluorometer.

Additional file 3: Fluorescence data in bioassays for the whey fractions prepared from different brands of milk (a-c) and yoghurt ( $d$ and e) using the solid phase biosensor (CadC-GFP and $\left.P_{\text {cad }}-O_{\text {cad }}\right)$ and fluorometer.

Competing interests

The authors declare that they have no competing interests.

\section{Authors' contributions}

MSRS performed all data acquisition, data analyses, and manuscript writing. IM and SU contributed to conception of the study, experimental design, and revision of manuscript. The manuscript was finally read and approved by all co-authors to be published.

\section{Acknowledgements}

This work was supported by a Grant-in-Aid from the Utsunomiya University Center for Optical Research \& Education (CORE) to IM. We would like to express our sincere gratitude to Dr. Hitoshi Sekimoto, Faculty of Agriculture, Utsunomiya University, Japan for his kind help in sample preparation by microwave-induced combustion of milk and yoghurt.

Received: 22 April 2012 Accepted: 16 October 2012

Published: 25 October 2012

\section{References}

1. Mandal BK, Suzuki KT: Arsenic round the world: a review. Talanta 2002, 58:201-235.

2. Buldini PL, Cavalli $P$, Sharma JL: Matrix removal for the ion chromatographic determination of some trace elements in milk. Microchemical J 2002, 72:277-284.

3. Hristov AN, Hazen W, Ellsworth JW: Efficiency of use of imported magnesium, sulfur, copper, and zinc on Idaho dairy farms. J Dairy Sci 2007, 90(6):3034-3043

4. Kim KW, Bang S, Zhu Y, Meharg AA, Bhattacharya P: Arsenic geochemistry, transport mechanism in the soil-plant system, human and animal health issues. Environ Int 2009, 35:453-454.

5. Licata P, Trombetta D, Cristani M, Giofre F, Martino D, Calo M, Naccari F: Levels of "toxic" and "essential" metals in samples of bovine milk from various dairy farms in Calabria, Italy. Environ Int 2004, 30:1-6.

6. Vidovic M, Sadibasic A, Cupic S, Lausevic M: Cd and Zn in atmospheric deposit, soil, wheat, and milk. Environ Res 2005, 97:26-31.

7. Ayar A, Sert D, Akin N: The trace metal levels in milk and dairy products consumed in middle Anatolia-Turkey. Environ Monit Assess 2009, 152:1-12.

8. Enb A, Abou Donia MA, Abd-Rabou NS, Abou-Arab AAK, El-Senaity MH: Chemical composition of raw milk and heavy metals behavior during processing of milk products. Global Veterinaria 2009, 3:268-275.

9. Abdolmohammad-Zadeh H, Sadeghi GH: A novel microextraction technique based on 1-hexylpyridinium hexafluorophosphate ionic liquid for the preconcentration of zinc in water and milk samples. Anal Chim Acta 2009 , 649:211-217.
10. Bhattacharya P, Hasan MA, Sracek O, Smith E, Ahmed KM, von Bromssen M, Huq SM, Naidu R: Groundwater chemistry and arsenic mobilization in the Holocene flood plains in south-central Bangladesh. Environ Geochem Health 2009, 31(Suppl 1):23-43.

11. Mukherjee A, Sengupta MK, Hossain MA, Ahamed S, Das B, Nayak B, Lodh D, Rahman MM, Chakraborti D: Arsenic contamination in groundwater: a global perspective with emphasis on the Asian scenario. $J$ Health Popul Nutr 2006, 24:142-163.

12. FAO/WHO: Evaluation of certain contaminants in food. World Health Organ Tech Rep Ser 2011, (959):1-105.

13. Kawakami Y, Siddiki MSR, Inoue K, Otabayashi H, Yoshida K, Ueda S, Miyasaka $\mathrm{H}$, Maeda I: Application of fluorescent protein-tagged trans factors and immobilized cis elements to monitoring of toxic metals based on in vitro protein-DNA interactions. Biosens Bioelectron 2010, 26:1466-1473.

14. Siddiki MSR, Kawakami Y, Ueda S, Maeda I: Solid phase biosensors for arsenic or cadmium composed of a trans factor and cis element complex. Sensors (Basel) 2011, 11:10063-10073.

15. Tillett T: Is arsenic "lactation intolerant"? Environ Health Perspect 2008, 116(7):A306

16. Pabon ML, Lonnerdal B: Bioavailability of zinc and its binding to casein in milks and formulas. J Trace Elem Med Biol 2000, 14:146-153.

17. Zhang P, Allen JC: Free zinc concentration in bovine milk measured by analytical affinity chromatography with immobilized metallothionein. Biol Trace Elem Res 1995, 50:135-148.

18. Brandao GC, de Jesus RM, da Silva EG, Ferreira SL: Use of slurry sampling for the direct determination of zinc in yogurt by high resolutioncontinuum source flame atomic absorption spectrometry. Talanta 2010, 81:1357-1359.

19. Blakeborough P, Salter DN, Gurr MI: Zinc binding in cow's milk and human milk. Biochem / 1983, 209(2):505-512.

20. Cervera ML, Lopez JC, Montoro R: Arsenic content of Spanish cows' milk determined by dry ashing hydride generation atomic absorption spectrometry. J Dairy Res 1994, 61:83-89.

doi:10.1186/1472-6750-12-76

Cite this article as: Siddiki et al:: Fluorescent bioassays for toxic metals in milk and yoghurt. BMC Biotechnology 2012 12:76.

\section{Submit your next manuscript to BioMed Central and take full advantage of:}

- Convenient online submission

- Thorough peer review

- No space constraints or color figure charges

- Immediate publication on acceptance

- Inclusion in PubMed, CAS, Scopus and Google Scholar

- Research which is freely available for redistribution 